\title{
合成梁と鉄骨梁の載荷加熱実験 FIRE RESISTANCE TESTS ON COMPOSITE AND STEEL BEAM
}

\author{
西垣太郎 — $* 1 \quad$ 杉田和直 $-* 2$ \\ 森本恭行 一 $*$ - 3 \\ キーワード : \\ 合成梁, 鉄骨梁, 梁の伸びだし，載荷加熱実験
}

Keywords :

Composite beam, Steel beam, Thermal expansion, Fire resistance test

\section{Taro NISHIGAKI — $* 1 \quad$ Kazunao SUGITA $-* 2$ \\ Yasuyuki MORIMOTO $-* 3$}

In this study, the fire resistance tests of the composite and the steel beam under loading were carried out in order to get fire resistive properties of a composite beam and to obtain basic data for the fire resitance design for CFT-Steel construction.

It was observed in the tests that the composite beam under live load and dead load was not collapsed even in high temperature (over $500^{\circ} \mathrm{C}$ ) and thermal expansion of the composite beam has the same tendency as that of the steel beam.

\section{1.はじめに}

火災時には、鉄骨梁に耐火被覆を施していても部材温度が上昇し熱 膨張する。その熱膨張により柱には部材角が生じ、耐力が劣化した柱 のP- ס効果により、架構が倒壊することが考えられる。このため、鋼 一コンクリートの組合せによる合成構造物の耐火設計においては、梁 の伸び出しの検討が必要であり、部材の温度上昇により略算では梁が 自由膨張すると仮定して評価している。新都市八ウジング協会による C F T 構造技術指針・同解説" ‘゙は、建築物の構造体を無被覆 C F T 柱とした場合、梁の伸び出しの影響を受けると考えられる柱の耐火性 能評価を、火災時の梁の伸び出しを自由膨張で評価し、部材角が $1 / 50$ 生じた状態で行うこととしている。なお、部材角が $1 / 50$ を越える場合 には適用範囲外としている。

しかし、鋼構造およびC F T 構造で一般的に使用されている合成梁 では、コンクリートスラブによる拘束や、火災階上階の健全な柱の剛 性など、様々な要因により梁の伸び出し量は抑えられるという考え方 がある。また一方、設計思想が性能設計へと移行するにあたり、現法 規では平均温度 $350^{\circ} \mathrm{C} 、$ 最高温度 $450^{\circ} \mathrm{C}$ に設定されている許容鎆材温度 が、平均温度 $500^{\circ} \mathrm{C} 、$ 最高温度 $600^{\circ} \mathrm{C}$ に設定される可能性も出てきてい る。このようなことから、火災時の構造安定性評価に大きな影響を与 える一要因である合成梁の耐火性状を把握しておく必要がある。

本報告では、火災時における合成梁の熱膨張による伸び出し量等の 耐火性状把握を目的として行った合成梁と鉄骨梁の載荷加熱実験につ いて報告する。

\section{2. 実験概要}

\section{1 試験体}

試験体形状寸法は、実施工された合成梁の調査結果と実験施設の形 状寸法を考虑し、実在の構造部材の一部を切り出したものとして、全 長 $7700 \mathrm{~mm}$ 、幅 $3000 \mathrm{~mm}$ 、高さ $1015 \mathrm{~mm}$ (鉄骨 $850 \mathrm{~mm}+$ コンクリート スラブ $165 \mathrm{~mm}$ )、支点間距離 $6800 \mathrm{~mm}$ 、加熱区間 $6000 \mathrm{~mm}$ とした。試 験体の形状および寸法を図ー1に示す。試験体は、コンクリートスラ ブの拘束効果を見るため合成梁と鉄骨梁の 2 体とした。

使用した鋼材とコンクリートの材料特性をそれぞれ表 -1 と表 -2 に示す。試験体の鉄骨部分に峛2 時間耐火仕様 [耐火 (通) G2211 ロックウール 吹き付け厚 $50 \mathrm{~mm}$ ] を目標に半湿式で平均厚 $54.1 \mathrm{~mm}$ の耐火被覆を施した。実験時の耐火被覆の含水率は $8.6 \%$ であった。

\section{表一 1 鋼材の材料特性}

\begin{tabular}{|c|c|c|c|c|c|}
\hline & 鋼種 & $\begin{array}{c}\text { 降伏点 } \\
\left(\mathrm{N} / \mathrm{mm}^{2}\right)\end{array}$ & $\begin{array}{c}\text { Tンク係数 } \\
\left(\times 10^{5}\right. \\
\left.\mathrm{N} / \mathrm{mm}^{2}\right) \\
\end{array}$ & $\begin{array}{l}\text { 引張強度 } \\
\left\langle\mathrm{N} / \mathrm{mm}^{2}\right\rangle\end{array}$ & $\begin{array}{l}\text { 伸び } \\
(\%)\end{array}$ \\
\hline 鉄骨ウエブ & \multirow[t]{2}{*}{ SM490A } & 452 & 2.17 & 574 & 25.8 \\
\hline 鉄骨フランジ & & 384 & 2.10 & 523 & 31.3 \\
\hline スタッド & SWCH16A & 345 & - & 458 & 39.0 \\
\hline 溶接金網 & & 534 & 2.00 & 625 & 8.7 \\
\hline
\end{tabular}

\begin{tabular}{|c|c|c|c|c|c|c|}
\hline 材令（日） & 菱生方法 & $\begin{array}{l}\text { 压㩁強度 } \\
\left(\mathrm{N} / \mathrm{mm}^{2}\right)\end{array}$ & $\begin{array}{l}\text { 引張強度 } \\
\left(\mathrm{N} / \mathrm{mm}^{2}\right)\end{array}$ & $\begin{array}{c}\text { ヤンク保数 } \\
\left(\times 10^{4}\right. \\
\left.\mathrm{N} / \mathrm{mm}^{2}\right)\end{array}$ & ポアソン比 & $\begin{array}{c}\text { 含水啝 } \\
(\%)\end{array}$ \\
\hline \multirow{2}{*}{$\begin{array}{c}254 \\
\text { (実験開始日) }\end{array}$} & 標準 & 42.4 & - & - & - & - \\
\hline & 現煬封絽 & 39.5 & 3.20 & 2.91 & 0.22 & 7.12 \\
\hline
\end{tabular}

*1 Chief Research Engineer, Technology Research Institute, Taisei Corporation, Dr. Eng.

1 侏大成建設技術研究所 主席研究員 - 丁博

(广245-0051 横浜方戸塚区名瀬町344-1)

*2 侏大成建設技術研究所 主席研究員・博上(工学)

*3 侏大成建設技術研究所 研究員
*2 Chief Research Engineer, Technology Research Institute, Taisei Corporation, Dr. Eng.

*3 Research Engineer, Technology Research Institute, Taisei Corporation 


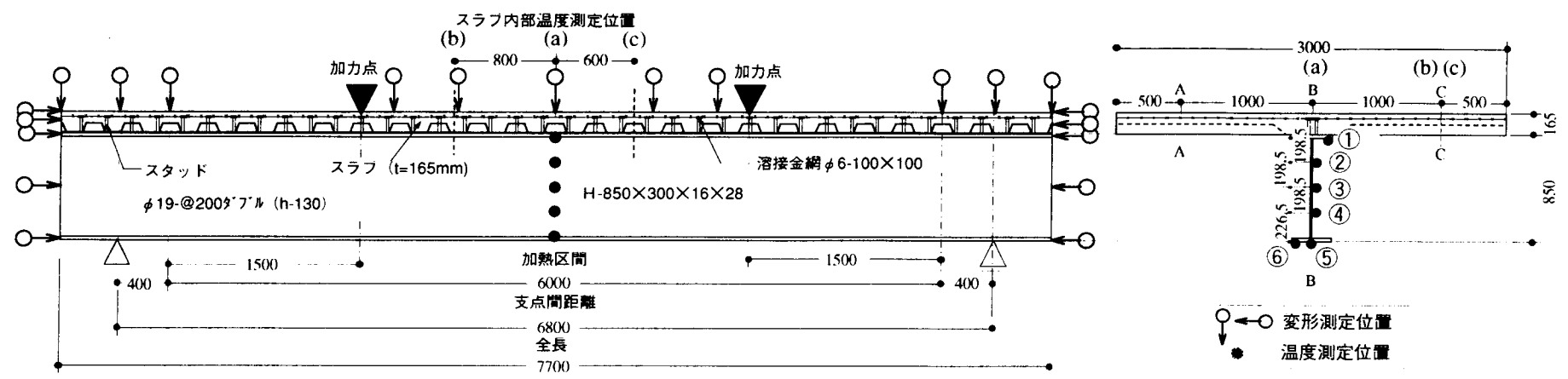

図-1試験体形状（合成梁）
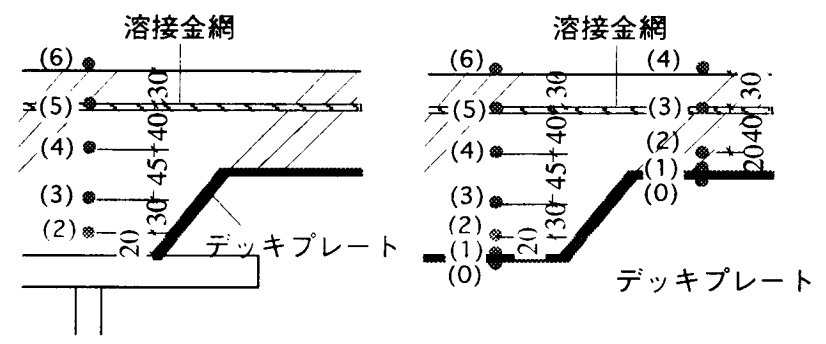

(a) 梁上部

（c）スラブ山部分

図一2 スラブ内部温度測定位置

\section{2 載荷および加熱方法}

載荷は、図一 1 に示すように試験体を単純支持し、加熱区間の 4 等 分点の 2 点（加熱区間両端から $1500 \mathrm{~mm}$ の位置）を加力点とし、それ

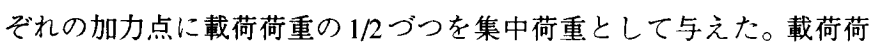
重は、実構造部材が受けると考えられる長期設計荷重時の応力と試験 体の応力を一致させるよう、合成梁 $0.52 \mathrm{MN}$ (応力 : $48.27 \mathrm{~N} / \mathrm{mm}^{2}, \mathrm{M} /$ $\mathrm{My}: 0.13$ )、鉄骨梁 $0.41 \mathrm{MN}$ (応力: $48.27 \mathrm{~N} / \mathrm{mm}^{2}$, M/My: 0.13) とした。 荷重は加熱前に載荷し、加熱開始から実験終了まで一定に保持した。 加熱は試験体上部を非加熱側として、JIS A 1304 の標準加熱温度曲線 に従い行った、試験体と炬との間にできる隙間は、耐火モル夕ルを用 いた炉蓋と、七ラミックブランケットで盖生した。実験は鋼材の平均 温度が $500^{\circ} \mathrm{C}$ あいは最高温度が $600^{\circ} \mathrm{C}$ に達するか、もしくは荷重を 支持できなくなるまで行うこととした。なお、実験は大成建設 (株) 技 術研究所の多目的炉 (炉内寸法: $6000 \mathrm{~mm} \times 3000 \mathrm{~mm} \times$ 深さ $4000 \mathrm{~mm}$ 燃料 : 灯油) と $20 \mathrm{MN}$ 載荷装置を用いて行った。

\section{3 測定項目}

実験では、図－1および図－2に示すように、鋼材温度、スラブ内 部温度、試験体の鉛直方向変形、水平方向変形および炉内温度を測定 した。試験体温度測定には線径 $0.65 \mathrm{~mm} の \mathrm{~K}$ 型熱電対を用い、変形測 定には電気式変位計を用いた。

\section{3. 実験結果および考察}

合成梁は、 240 分で鋼材平均温度が $500^{\circ} \mathrm{C}$ に達したため実験を終了 した。鉄骨梁は、横座屈防止のスチフナ補強がされておらず、横座屈 により酎火炉の内部を損傷する可能性があるため、152分で実験を終 了した。合成梁では、実験終了時に梁の局部座屈・横座屈などは生じ ず、試験後の観察においても耐火被覆の剥離、剥落は認められなかっ た。実験結果を以下にまとめて示す。

\section{1 炉内温度と加熱時間の関係}

実験時の炬内温度の一例として、合成梁の載荷加熱実験における炉 内温度一時間の関係を図ー3に示す。炉内温度は標準加熱温度曲線と

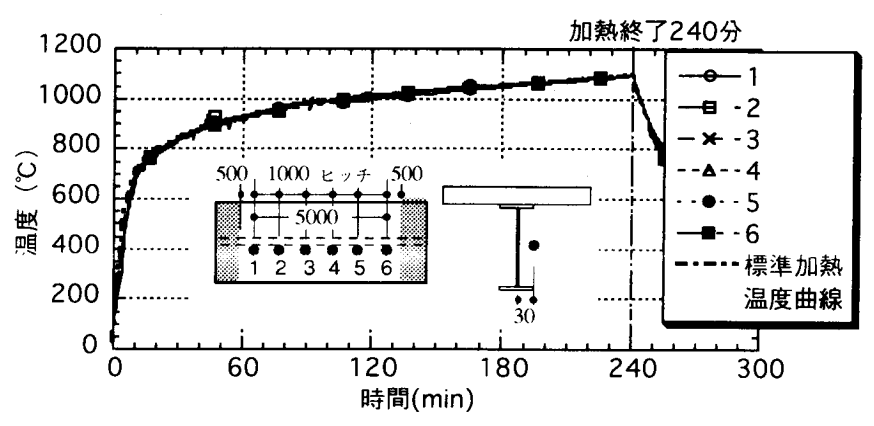

図－3 炉内温度一時間の関係（合成梁）

よく一致して㧍り、加熱は適切な条件で行われた。なお、図には省略 したが、鉄骨梁も同様な加熱が行われた。

\section{2 試験体温度と加熱時間の関係}

合成梁試験体のコンクリートスラブ内部温度一時間の関倸を図 -4 (a) 〜 (c) に、スラブ内部温度分布一時間の関倸を图一5 (a) 〜 (c) に 示す。スラブ内部温度は、スパン中央位置の鉄骨梁上部（厚さ $165 \mathrm{~mm}$ )、スラブ谷部分（厚さ $165 \mathrm{~mm}$ )、スラブ山部分（厚さ $90 \mathrm{~mm}$ ) の 3 断面を示す。

梁上部が他の断面に比べ緩やかな温度上昇を示している。これは、 スラブ谷部分と山部分ではデッキプレートが直接加熱されているのに 対して、鉄骨に接合されている梁上部のスラブは直接には加熱されて いないため、流入する熱量が少なかったと考えられる。また、スラブ 内温度が $100^{\circ} \mathrm{C} て ゙$ 停滞する現象が現れており、その停滞時間が加熱面 からの距離が大きいほど長くなっている。これは加熱側のコンクリー ト中の水分が、温度上昇により膨張·蒸発してコンクリート内にある 空隙の圧力が大きくなり、水分や蒸気が圧力が低い加熱裏面側の空隙 へと移動したためと考えられる。スラブ裁面温度は、図ー5 (c) に示 すスラブ厚の薄い [スラブ山部分] でもっとも上昇し、加熱時間 120 分で $117.9^{\circ} \mathrm{C} 、 180$ 分で $194.2^{\circ} \mathrm{C}$ 、加熱終了時の 240 分で $290^{\circ} \mathrm{C}$ であった。 各試験体の加熱区間中央の鋼材温度一時間の関係を図－6および図 ー7に示す。鋼材の温度がスラブ内部温度と同様に約 $100^{\circ} \mathrm{C} て ゙$ 停滞し ているのが見られるが、これは耐火被覆中の水分が移動・蒸発し、鋼 材の熱が奪われているためと考えられる。同じ加熱時間においては、 合成梁の方が高い温度を示した。これはコンクリートスラブからの熱 損失が大きいため、炬内温度を上昇させるのに必要な火力が大きく なったためと考えられる。加熱終了時の鋼材平均温度は合成梁約 550 ${ }^{\circ} \mathrm{C} 、$ 鉄骨梁約 $260^{\circ} \mathrm{C}$ あっった。

\section{3 梁の水平方向変形と加熱時間の関係}

各試験体の梁の伸び変形一時間の関係を図ー8および図-9に示す。 鉄骨梁加熱終了時の加熱時間 152 分での伸び量を比較すると、合成梁 の方が鉄骨梁に比べて大きくなっている。この要因として、合成梁の 


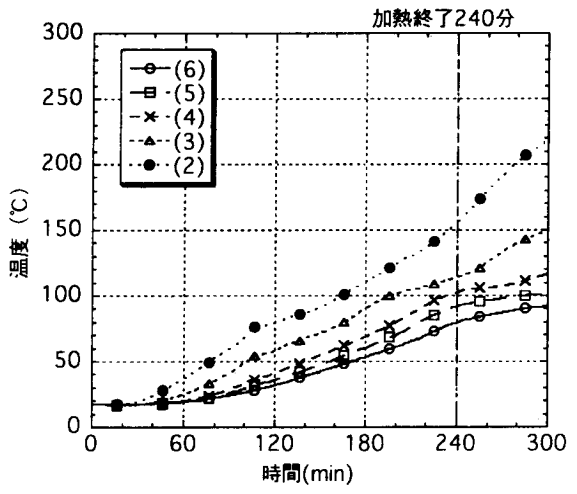

(a) 梁上部

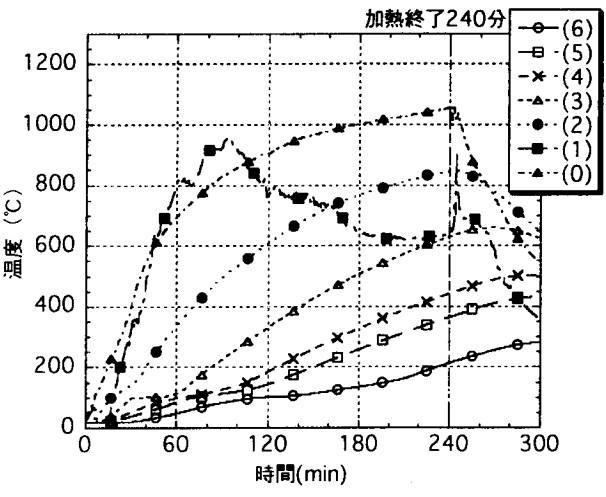

(b) スラブ谷部分

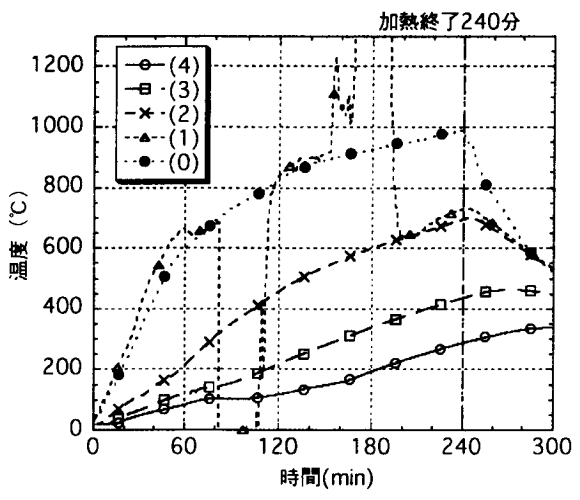

（c）スラブ山部分

図一4 試験体温度一時間の関係（合成梁 スラブ内部）

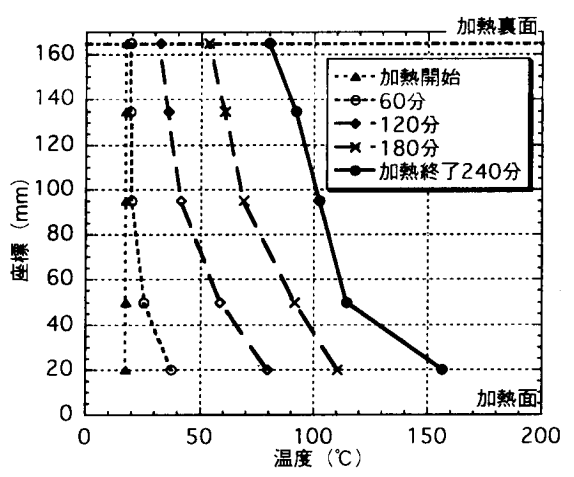

(a) 梁上部

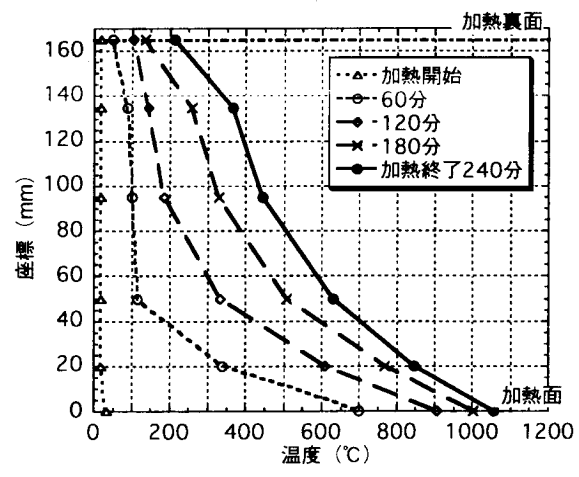

(b) スラブ谷部分

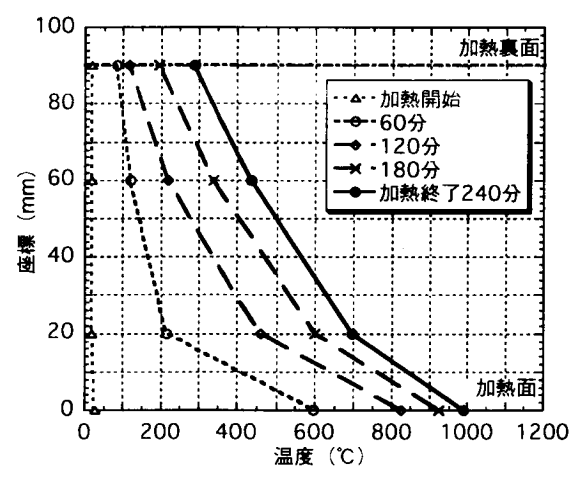

(c) スラブ山部分

図一5 試験体温度一時間の関係（合成梁 スラブ内部温度分布）

方が鋼材温度が高くなっていることが考えられ る。また、両試験体とも加熱が進むにつれて梁 上部と梁下部の伸び量の差が大きくなっている。 これは梁の上部と下部の温度差が大きくなった ことと鋼材の温度上昇による剛性低下により、 曲率が増大したためと考えられる。

\section{4 スラブの水平方向変形と加熱時間の関係}

合成梁におけるコンクリートスラブ各部位の 伸び変形一時間の関係を図一10に示す。変形は 図ー 1 に示すように、試験体の端部側面 A,B, $\mathrm{C}$ の 3 カ所で測定した。スラブの伸びは、A，C に比べてBが小さい。これは3.2 と同様の理由に

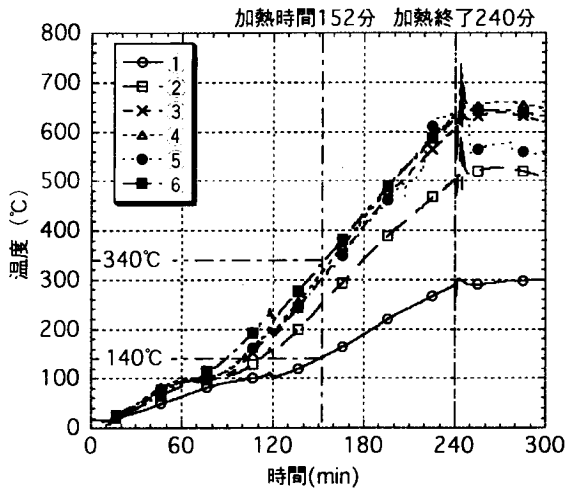

図一 6 試験体温度一時間の関係（合成梁）

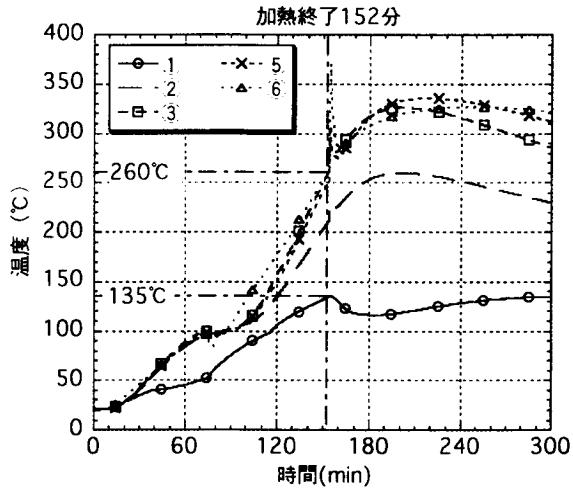

図-7 試験体温度一時間の関係（鉄骨梁）
より、鉄骨の上部のスラブは内部温度が上がりにくく、温度上昇によ る伸びが小さかったためと考えられる。このように伸び量に差が出た ため、図ー $11 に$ 示すように鉄骨梁と平行なひび割れがスラブに生じた と考えられる。このひび割れにより、スラブが鋼材の伸びだしを拘束 する効果は、小さくなっていると考えられる。

\section{5 合成梁の鉄骨とスラブの水平方向変形の比較}

図ー12に鉄骨とスラブの伸び変形一時間の関係を示す。この図は鉄 骨とスラブの境界部分で、それぞれの伸び量を比較したものである。 スラブと鉄骨が一体となって伸びていれば同じ值を示すはずであるが、 加熱が淮むにつれて、鉄骨の方が大きく伸びだし、伸び量の差は加熱 時間 60 分で $1.5 \mathrm{~mm} 、 120$ 分で $2.6 \mathrm{~mm} 、 180$ 分で $4.0 \mathrm{~mm}$ と徐々に大きく なっている。よって、加熱が進むにつれ、鉄骨に溶接されたスタッド による合成効果が低下していると考えられる。

\section{6 鉛直方向変形と加熱時間の関係}

各試験体スパン中央の加熱開始時からのたわみ増加量一時間の関係 を図ー13に、たわみ速度一時間の関係を図ー14に示す。合成梁と鉄 骨梁がそれぞれほほ同じ傾向で推移した。

試験体のたわみは、加熱が進むにつれて、熱少化と熱応力により増 大した。加熱開始から終了までのたわみ増加量は、合成梁 $44 \mathrm{~mm} 、$ 鉄 骨梁 $19 \mathrm{~mm}$ で両試験体とも破壊の判定值（ISO834： L L2/400d 合成梁 $113 \mathrm{~mm}$, 鉄骨梁 $136 \mathrm{~mm}, \mathrm{~L}$ : スパン, d: 試験体のせい) に至っていな い。なお、図中には参考のため旧 ISO834の判定值 $\left(\mathrm{L}^{2} / 800 \mathrm{~d}\right.$ ：合成梁 $57 \mathrm{~mm}$, 鉄骨梁 $68 \mathrm{~mm}$ ）も示した。

たわみ速度は、加熱時間 50 分までは増加し、その後隇少して加熱 時間 80 分でほほ $0 \mathrm{~mm} / \mathrm{min}$ となった。この時間帯は、酎火被覆により 鋼材温度が停滞していたため、温度上昇による剛性低下が小さかった 

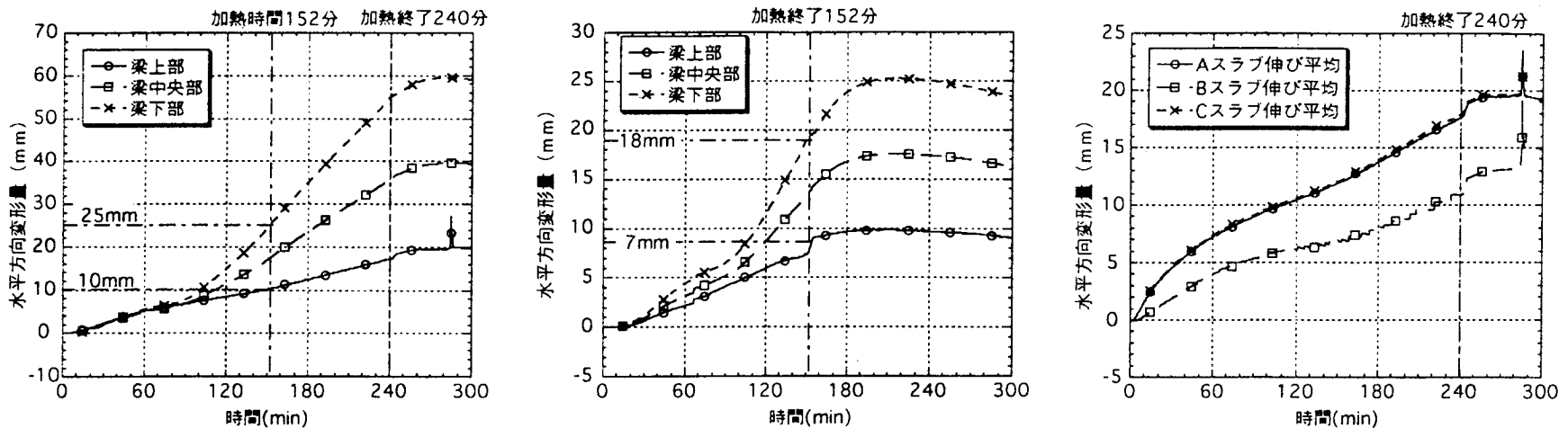

図一8 梁の伸び変形一時間の関係（合成梁）

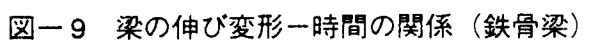

図一 10 スラブの伸び一時間の関係（合成梁）
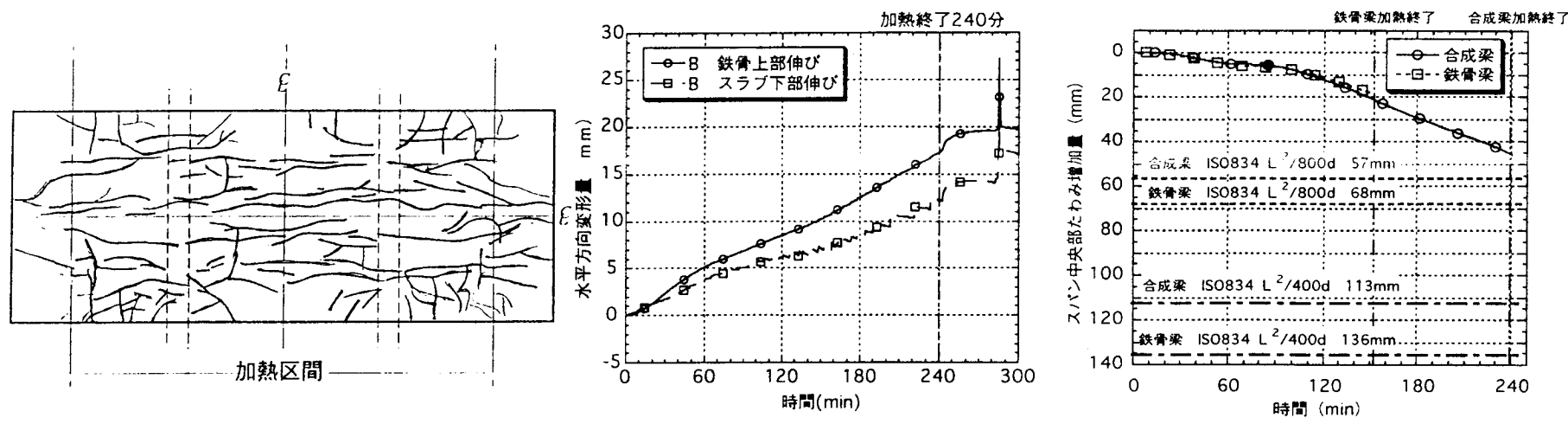

図一11 実験後の試験体ひび割れ図（合成梁）図一12 鉄骨とスラブの伸び比較（合成梁）

図一13 たわみ増加量一時間の関係

と考えられる。その後、鋼材の温度が上昇し部 材の剛性低下が淮むにつれて、たわみ速度は大 きくなった。たわみ速度もたわみ增加量と同様 に、破壊の判定值 (ISO834：L²/9000d 合成梁 $5 \mathrm{~mm} / \mathrm{min}$ ，鉄骨梁 $6 \mathrm{~mm} / \mathrm{min}$ ）を越えなかった。

\section{7 梁の伸びと鋼材温度の関係}

梁の伸び出し量一鋼材温度の関倸を図一15: 示す。梁の伸び出し量および銅材温度は平均值 で評価し、実験値と温度依存させた線膨張係数 $\left(\left(11.0+5.75 \times 10^{-3} \mathrm{~T}_{\mathrm{s}}\right) \times 10^{-6} / \mathrm{C}, \mathrm{T}_{\mathrm{s}}:\right.$ 鋼材温度 $)$ を用いて略算した計算値とを比較した。合成梁 と鉄骨梁の伸び出し量は、鋼材温度とほほ比例

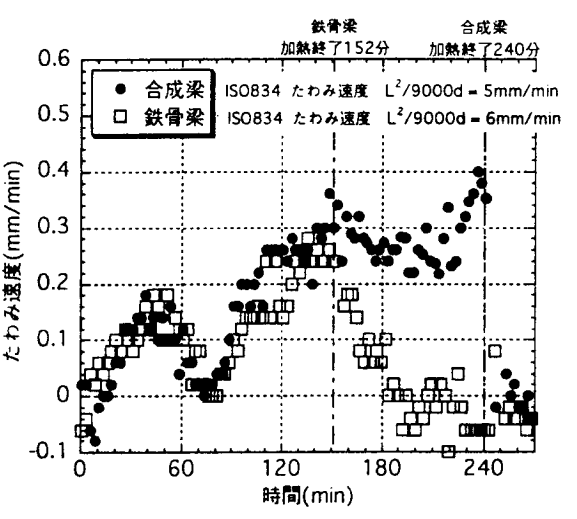

図ー14 たわみ速度一時間の関係

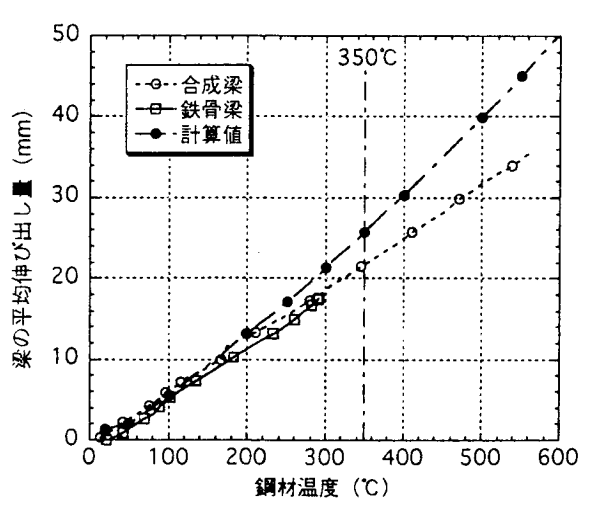

図一 15 梁の伸びー温度の関係

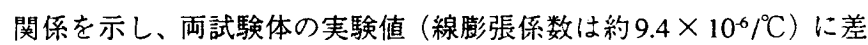
は認められなかった。よって、コンクリートスラブによる梁の伸び だしの拘束はなかったと考えられる。各試験体の伸び量は、鋼材温 度が低い領域では計算值との差がほとんど見られなかったが、龬材 温度が 200 Cに達するあたりから実験値の方が小さな值を示した。現

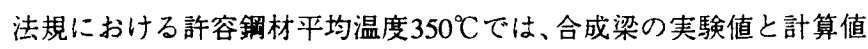
との差は $5 \mathrm{~mm}$ となった。

\section{4. まとめ}

実験結果の考察から得られた知見を以下に示す。

1) 本実験では、合成梁と鉄骨梁の伸び出し量に差は見られず、コン クリートスラプの拘束力は認められなかった。これは、鉄骨に平行 なひび割れがコンクリートスラブに生じたことと、部材の温度上昇 によりスタッドによる合成効果が低下したことにより、鋼材の伸び だしに対するスラブの拘束力がなくなったためと考えられる。

2）梁の伸び出しの実験値は、計算値に比べて小さな值を示したこと
から、略算による梁の伸び出しの評価は、安全側で行われていること が確認された。

3）単純支持である本実験の合成梁は、鋼材平均温度 $5000^{\circ} \mathrm{C}$ 高温に達 しても、梁の局部座屈・横座屈等が生じず、耐火被覆の剥離、剥落も なかった。また、試験体の変形はISO834の判定値よりかなり小さかっ

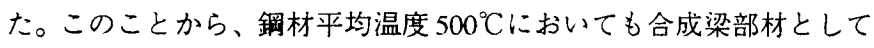
安定していると考えられる。

以上の実験結果は、CFT構造などの耐火設計を行う際に有用なデー 夕になると考える。ただし、本実験は梁部材を単体として扱った場合 であるため、今後は他の部材との関連性を考虑した実験が必要であ る。

\section{参考文嗝}

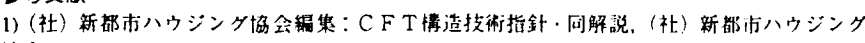
挆会, 1997

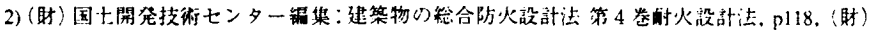
日本建築センター, 1989

[1998年 6 月26日原稿受理 1998年11月 4 日採用決定］ 